Bangladesh J. Bot. 37(1): 61-65, 2008 (June)

\title{
LICHEN FLORA IN CHANDRA SAL FOREST: OCCURRENCE, DISTRIBUTION AND ABUNDANCE
}

\author{
Nuhu Alam and M.A. Gafur ${ }^{1}$ \\ Department of Botany, Jahangirnagar University, Savar, Dhaka-1342, Bangladesh
}

Key words: Lichen, Occurrence, Distribution, Abundance, Sal forest

\begin{abstract}
Occurrence of lichen flora in Chandra Sal Forest of Gazipur district, Bangladesh revealed 12 taxa under 2 genera of lichens. These are Anaptychia sp., Anthracothecium variolosum, Bacidia luteola, Chiodecton philippinum, Dimelaena sp., Graphis scripta, Lecanora rugosa, Leptogium sp., Parmelia conspersa, Pertusaria sp., Rhizocarpon sp. and Tylophoron moderatum. The taxa were identified from four different locations of Chandra Sal forest. Symbiotic relationship between algae and fungi revealed that a total of five algal genera namely, Anabaena sp., Gloeocapsa sp., Nostoc sp., Protococcus sp. and Trentepohlia sp. were found to form the thalli of lichens individually with ascomycetous fungi. Nostoc sp. and Protococcus sp. each was found separetely in four lichens.
\end{abstract}

\section{Introduction}

Bangladesh is a subtropical country and its climatic condition favours the growth of different lichens on the bark of trees, rocks, soils, etc. The wide diversity of lichen flora has encouraged many researchers to investigate their distribution, taxonomy, ecology and biological activity (Din et al. 1992). Sipman (1993) reported a total of 286 species of lichen from Mount Kinabalu, Malaysia. To date, there are a few published reports on the lichens of South East Asia. Some earlier studies were done by Sammy (1980) and Din et al. (1995). Considering the facts, the present research work was undertaken to investigate the occurrence, distribution and abundance of lichens in Sal (Shorea robusta Gaertn.) forest and to isolate and identify fungi and algae from lichens.

\section{Materials and Methods}

Lichen samples were collected from four sites of Chandra Sal forest such as north, south, east and west sites. From each site five different trees of same species were randomly selected. Sharp knife and a scalpel were used for collecting whole thallus of the lichens from the bark kept in airtight polyethylene bags and brought to the laboratory. All the samples were preserved in the refrigerator until identification and microscopic study.

The samples were observed and studied under simple microscope. Each thallus was sectioned and fungal structure was separated from the algal component. The fungal body was mounted on slides in lactophenol as well as in cotton blue. Slides were prepared for identifying the isolated lichens by using different chemicals. The chemicals used for softening the sample tissues were: iodine solution (0.5\%), potassium hydroxide solution $(0.5 \%)$, calcium chloride solution $(0.5 \%)$ and glycerin (30\%). The fungi were identified with the help of keys outlined by Chopra and Chowdhury (1934) and Mishra and Agarwal (1978).

In order to isolate algal components from the collected lichens of Sal trees, small piece of lichen thallus was separated from the whole body by a sharp blade and placed in the sterilized Chu-10D medium for culture. After 21 days algal growth was observed and identified.

\footnotetext{
${ }^{1}$ Corresponding author: Department of Botany, University of Chittagong, Chittagong-4331, Bangladesh.
} 
The presence of lichen thalli on four different sides of Chandra Sal forest is shown in Table 1. During the investigation seven species of lichens under five genera were identified. The identified lichens were Anaptychia sp., Anthracothecium variolosum, Bacidia luteola, Chiodecton philippinum, Dimelaena sp., Graphis scripta, Lecanora rugosa, Leptogium sp., Parmelia conspersa, Pertusaria sp., Rhizocarpon sp. and Tylophoron moderatum.

Table 1. Occurrence of lichens on four sides of Chandra Sal forest.

\begin{tabular}{lcccc}
\hline \multirow{2}{*}{ Lichens } & \multicolumn{2}{c}{ Lichens recorded on four different sides of Chandra Sal forest } \\
\cline { 2 - 5 } & North side & South side & East side & West side \\
\hline Anaptychia sp. & + & + & + & + \\
Anthracothecium variolosum & + & - & + & - \\
Bacidia luteola & + & - & + & + \\
Chiodecton philippinum & + & + & + & - \\
Dimelaena sp. & - & + & + & - \\
Graphis scripta & + & + & + & - \\
Lecanora rugosa & - & - & + & + \\
Leptogium sp. & + & - & + & - \\
Parmelia conspersa & + & + & + & + \\
Pertusaria sp. & + & + & + & + \\
Rhizocarpon sp. & + & + & & + \\
Tylophoron moderatum & + & & + \\
\hline
\end{tabular}

'- not detected.

The lichens identified in the present study were also recorded from Darjeeling and Sikkim Himalayas by Chopra and Chowdhury (1934). Dobson (1979) identified 13 species of lichens representing 11 genera. The identified lichens were Anaptychia sp., Bacidia sp., Graphis sp., Haematomma sp., Lecanora sp., Leptogium sp., Parmelia sp., Pertusaria multipuncta, Rhizocarpon sp., Rinodina sp. and Usnea sp. Among these lichens only eight genera namely, Anaptychia sp., Bacidia sp., Graphis sp., Lecanora sp., Leptogium sp., Parmelia sp., Pertusaria multipuncta, and Rhizocarpon sp. were similar to those collected from Chandra Sal forest in Gazipur which are described below.

\section{Anaptychia sp.}

Thallus orbicular or moderately broad, laciniate, horizontally spreading or slightly ascending at the circumference, branched multified and rounded. Apothecia numerous, large, varying from 1$8 \mathrm{~mm}$ in diameter. Asci clubshaped and 8 spores. Spore brownish, 1-septate, polariculars, and oblong measuring $43-55 \mu \mathrm{m}$ long.

\section{Anthracothecium variolosum Mull. Arg.}

Thallus epiphloedal, cracked areolate, waxy. Perithecia numerous, situated in a verrucae more or less immersed, black opening by small ostiole, hymenium turning golden with iodine solution. Asci clavate with 2-4 large spores.

\section{Bacidia luteola Mudd.}

Thallus effuse, thin, leprose, granulose, grayish green when moist but black when dry. Apothecia numerous, subglobose, sessile, ash-gray colored, at first concave becoming plane. Asci clavate with 5-8 spores. Spores pleuroseptate, straight, hymenium violet with iodine solution. 


\section{Chiodecton philippinum Waino}

Thallus crustaceous, thin, verruculose, furrowed. Apothecia and spermogones absent. Asci clubshaped. Spore muriform, colorless, septate.

\section{Dimelaena sp.}

Thallus crustaceous, superficial, epiphloedal, subdeterminate. Apothecia numerous, black, wart like. Asci clavate, spore generally 8 in the ascus. Paraphysis slender, tips brownish. Spores ellipsoid, 1 septate, brown color, thick walled.

\section{Graphis scripta (Fee) Mull. Arg.}

Thallus thin, sub tertaraceous, grayish white, slightly wrinkled, limited by a black line. Apothesia elongate, slender, immersed then erumpent, thalline margin wavy and crisp. Paraphysis slender, slightly swollen and brownish at the tips. Asci clavate. Spores are colorless, elongate cylindrical, 7-10 septate.

\section{Lecanora rugosa $\mathrm{Nyl}$.}

Thallus generally determinate, thickish up to the margin, wrinkled, granulate or warted, unequal, grayish-green. Apothecia scattered or crowded, moderate in size, thalline margin thick, crenulate. Paraphysis slender, septate. Asci clavate. Spore ellipsoid, generally 8 in the ascus, measuring 11-15 $\mu \mathrm{m}$ long.

\section{Leptogium sp.}

Thallus lobate, lobes moderate in breadth, membranaceous, margins crisp and undulated. Apothecia rare. Asci and ascospore not detected.

\section{Parmelia conspersa Ach.}

Thallus horizontal, appressed and horizontal margin, lobate, laciniate, lacinae linear, deeply multiplied with convex and spreading apices. Apothecia not present. Asci and ascospore not detected.

\section{Pertusaria sp.}

Thallus crustaceous, epiphloedal, subdeterminate, areolate, verruculose and wrinkled, dotted with flat, white, sorediate verrucae. Apothecia numerous, small 1-3 immerged in the thalline verrucae, disc rather wide and not ostioler, thalline margin thin. Asci clavate, contain single large spore, septate, separating a round mass of protoplasm from the tip.

\section{Rhizocarpon sp.}

Thallus greenish black and crustaceous, usually with distinct color. Apothecia usually dark color and carbonaceous, immerginate or with proper margin only.

Asci clavate, asci 8 or few spores. Spore ellipsoid or oblong, brownish, septate, usually with hyaline.

\section{Tylophoron moderatum Nyl.}

Thallus crustaceous, membranaceous, bluish grey, verruculose, surface pruinose. Apothecia numerous, situated in the thalline warts, crowded or solitary, subsessile, disc black with globbose, mass of spore projecting upwards. Asci clavate. Spore small, brownish black, 1- septate, ellipsoid to spindle form. 
Associated algae with different lichens are presented in Table 2. The highest number of lichens was found with both Nostoc sp. and Protococcus sp. and rest of the lichens were found as a single association of algae. Nostoc was found associated with four lichens namely Chiodecton philippinum, Leptogium sp., Pertusaria sp. and Rhizocarpon sp. where as Protococcus was also found to be associated with four lichens namely- Anaptychia sp., Anthracothecium variolosum, Bacidia luteola and Lecanora rugosa. Rest of the lichens namely, Dimelaena sp., Graphis scripta and Tylophoron moderatum was found associated with Anabaena sp., Trentepohlia sp. and Gloeocapsa sp., respectively. The algal portion of Parmelia conspersa could not be identified.

Table 2. Lichens and the associated phycobionts.

\begin{tabular}{|c|c|c|c|c|c|}
\hline \multirow{2}{*}{ Lichens } & \multicolumn{5}{|c|}{ Genera of associated algae } \\
\hline & Anabaena & Gloeocapsa & Nostoc & Protococcus & Trentepohlia \\
\hline Anaptychia sp. & - & - & - & + & - \\
\hline Anthracothecium variolosum & - & - & - & + & - \\
\hline Bacidia luteola & - & - & - & + & - \\
\hline Chiodecton philipinnum & - & - & + & - & - \\
\hline Dimelaena sp. & + & - & - & - & - \\
\hline Graphis scripta & - & - & - & - & + \\
\hline Lecanora rugosa & - & - & - & + & - \\
\hline Leptogium sp. & - & - & + & - & - \\
\hline Parmelia conspersa* & - & - & - & - & - \\
\hline Pertusaria sp. & - & - & + & - & - \\
\hline Rhizocarpon sp. & - & - & + & - & - \\
\hline Tylophoron moderatum & - & + & - & - & - \\
\hline Total No. of Lichen & 1 & 1 & 4 & 4 & 1 \\
\hline
\end{tabular}

‘_' not detected. *Algal portion could not be detected.

Results on the symbiotic relationship between algae and fungi revealed that in all five algal genera namely - Anabaena sp., Gloeocapsa sp., Nostoc sp., Protococcus sp. and Trentepohlia sp. were found to form the thallic body of lichens with ascomycetous fungi which corroborate with Chopra and Chowdhury (1934) and Mishra and Agarwal (1978).

The present investigation revealed wide variability in the association of fungi and algae as well as their distribution in the Sal Forest of Chandra, Gazipur, Bangladesh.

\section{Acknowledgement}

The authors are thankful to Jahangirnagar University authorities for providing financial help.

\section{References}

Chopra, G.L. and H.P. Chowdhury. 1934. Lichens in the Himalayas. Part-1. Lichens of Darjeeling and Sikkim Himalayas with 12 Plates: Univ. Pubjab, Lahore. pp. 103.

Din, L.B., I.B. Ipor, B.A. Farihuddin and J.A. Elix. 1995. Additional lichen records from Indonesia and Malaysia. Australian Lichenological Newsletter 36: 27-28.

Din, L.B., Z. Zakaria, M.W. Samsuddin, I.B. Ahmed, A. Latif, N.I. Yusof and I.M. Said. 1992. Studies of Malaysian Lichen: distribution, chemotaxonomy and biological activity. In: Medical products from tropical rain forest (Khozirah et al. Eds.), pp. 44. Proc. Conf. Forest Res. Inst., Kualalumpur, Malaysia.

Dobson, F. 1979. Lichens - An illustration guide. Richmond Publishing Co. Ltd. U.K. pp. 317.

Farooque, M. 1997. Law and custom on forest in Bangladesh: Issues and remedies. Bangladesh Environ. Lawyers Assoc. (BELA). Dhaka, Bangladesh. pp. 99. 
Mishra, B.P. and R.P. Agarwal. 1978. Lichens. Oxford and IBH Publishing Company Ltd. New Delhi. pp. 103.

Sammy, N. 1980. Lichens from Gunnung Mulu National Park, Sarawak: East Malaysia. Part-1. Introductory Account. Malaysia Natu. J. 34: 57-63.

Sanders, W.B. 2001. "Lichens: Interface between mycology and plant morphology." Bioscience 51: 10251035.

Sipman, J.J.M. 1993. Lichens from Mount Kinabalu. Tropical Biology 8: 281-314.

(Manuscript received on 23 March, 2008; revised on 23 April, 2008) 